\title{
PREVALENCE OF SUBJECTIVE AND OBJECTIVE FACTORS IN PATIENTS WITH TEMPOROMANDIBULAR JOINT DISORDERS
}

\author{
Rugilè Nedzinskaitė, Ieva Perednytė \\ Vilnius Implantology Center Clinic, Medwell Clinic
}

Keywords: temporomandibular joint disorders, orofacial pain, stress, malocclusion.

\begin{abstract}
Summary
Aim and objectives: the aim of this work is to investigate prevalence of subjective and objective factors in patients with TMJ disorders.

Material and methods: this investigation is a part of a prospective study which was started in autumn of 2018. The investigation was performed in Hospital of Lithuanian University of Health Sciences Kaunas Clinics in the Department of Maxillofacial surgery and in the Department of Orthodontics. Investigation comprised of three parts - extraoral and intraoral investigation and two questionnaires about the patient's symptoms and health. There were 14 questions in patient's symptoms questionnaire about self-reported pain. In the questionnaire about health there were 9 questions about stress which was felt by the patient. Statistical analysis was performed using "Microsoft Office Excel" and "IBM SPSS Statistics 25 " software programs. To determine the statistical relationship between independent variables t-test and $\chi^{2}$ test were used.

Results: from October 4th, 2019 to February 4th, 202072 subjects were reffered to the Department of Maxillofacial surgery, Hospital of Lithuanian University of Health Sciences Kaunas Clinics. 50 eligble subjects were included into this research. Other data of additional 50 subjects was taken from the available earlier database. $80 \%$ of the subjects were female and $20 \%$ were male. $49 \%$ of the subjects were younger than 30 years old. $86,60 \%$ of included subjects suffered from pain in the temporomandibular joint area, in $2 / 3$ of them pain was chronic. $97 \%$ of the subjects were diagnosed with TMJ disorders, for $49,98 \%$ of them had disc dislocation with reduction was diagnosed and for 50,52\% - disc dislocation without reduction. All patients experienced stress. For $82,47 \%$ of them stress did not have an effect or had only a small
\end{abstract}

effect on their daily life, for $17,53 \%$ stress affected their daily life a lot. The most common malocclusion for all types of TMJ disorders was Angle class II malocclusion. Conclusions: there was a wide range of subjective and objective factors in patients with TMJ disorders. Angle class II malocclusion was the most common in all TMJ disorders.

\section{Introduction}

The prevalence of temporomandibular joint (TMJ) disorders has been comprehensively studied over the years [1]. TMJ disorders (TMDs) is a collective term used for a group of musculoskeletal and neuromuscular conditions that include several clinical signs and symptoms such as pain, TMJ sounds and TMJ locking [2]. These disorders have a multifactorial etiology, providing that a number of risk factors interact at the individual level and determine the onset of clinical signs and symptoms [3]. Through a compelling insight on the mutual interactions of pain, bruxism, and psychosocial factors, the pathophysiology of TMDs may be further clarified [3]. Every individual is subjective to certain factors of external environment and respond differently to the external stressors [1]. In nowadays world when pace of life is high and stress levels in everyday life are increased, an important role is played by the psychological factors in the onset and development of TMJ disorders [1].

TMJ disorders is the second most common chronic musculoskeletal condition after chronic low back pain [4]. It has been reported that about $5 \%$ to $12 \%$ of the United States population is affected by TMD [5]. An epidemiological study has shown that approximately $75 \%$ of adult population have at least one symptom related to TMJ dysfunction and 30\%two or more symptoms [6]. Patients tend to indicate different clinical symptoms: pain during mouth opening and chewing, clicking in the area of the temporomandibular joint or ear and limited mandibular opening [6]. The orofacial pain, which is also a TMD symptom, is an important public health problem and it should be diagnosed as early as possible since late dia- 
gnosis can lead to a more severely compromised state resulting in need for a complicated and expensive treatment [2].

In scientific literature studies are usually made with large common populations, therefore, there is a lack of studies that emphasize on the signs and symptoms of TMJ disorders in the population with TMJ disorders.

Aim and objectives: the aim of this work is to investigate prevalence of subjective and objective factors in patients with TMJ disorders.

\section{Subjects and methods}

This investigation is a part of a prospective study which was started in autumn of 2018. The investigation was performed in Hospital of Lithuanian University of Health Sciences Kaunas Clinics in the Department of Maxillofacial surgery and in the Department of Orthodontics. From October 4th, 2019 to February 4th, 202072 subjects were reffered to the Department of Maxillofacial surgery, Hospital of Lithuanian University of Health Sciences Kaunas Clinics. 50 eligble subjects were included into this research. Other data of additional 50 subjects was taken from the available earlier database. The sample of 100 people were selected for the study. Only people who met the following criteria were included into the study:

- Patients older than 18 years of age;

- Patients with objectively diagnosed TMJ disorder.

Investigation comprised of three parts - both extraoral and intraoral investigation and two questionnaires about the patient's symptoms and health. Extraoral and intraoral investigation was performed using special forms to diagnose TMJ disorders and evaluate occlusion (Document 1, table 1).

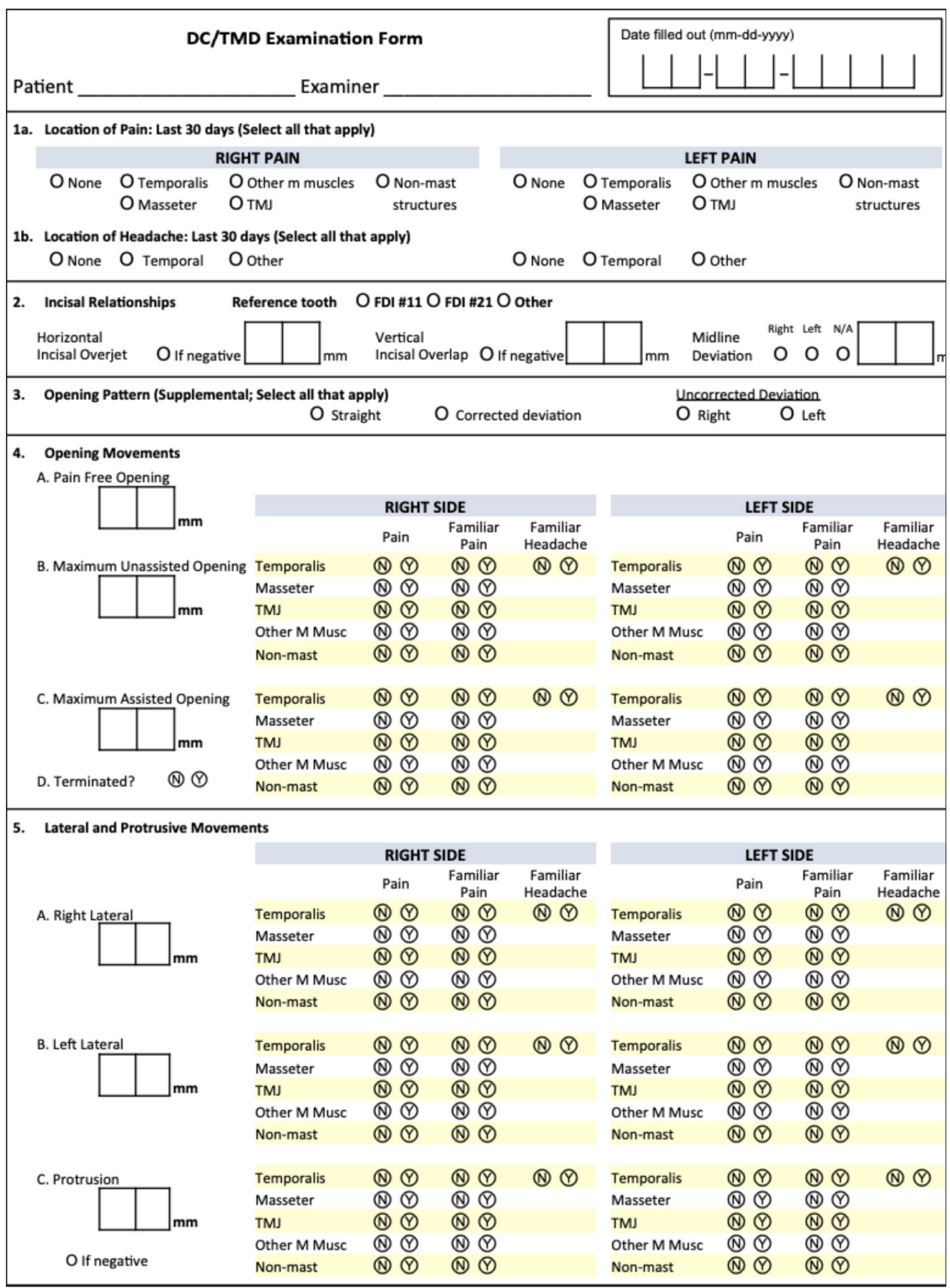


There were 14 questions in patient's symptoms questionnaire about self-reported pain. Patients were asked to describe and mark in the questionnaire where and for how long the pain was present, what was the type of the pain and what triggered the pain. In the questionnaire about health there were 9 questions about stress which was felt by the patient. Patients were asked to evaluate 9 statements in the questionnaire from " 0 " to " 3 " according to the frequency, "0" being none over the past two weeks and " 3 " being almost every day.

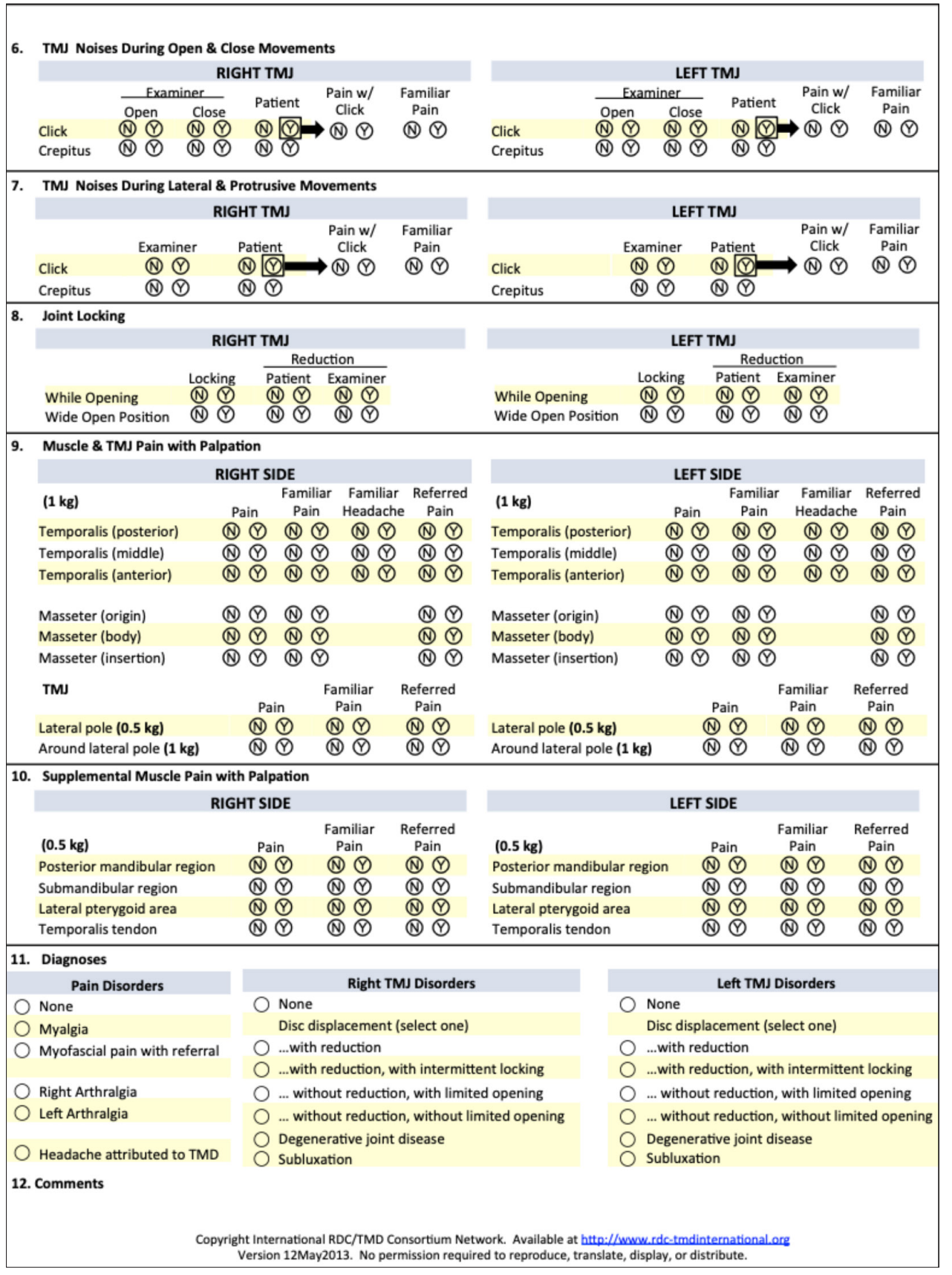

Document 1. DC/TMD Examination Form [18]
Statistical analysis was performed using "Microsoft Office Excel" and "IBM SPSS Statistics 25" software programs. To determine the statistical relationship between independent variables t-test and $\chi^{2}$ test were used.

\section{Results}

$80 \%(n=80)$ of the subjects were female and $20 \%$ $(n=20)$ were male. The average age of the subjects was $32.9(\mathrm{SD}=11,77)$ years and $49 \%(n=49)$ of the subjects were younger than 30 years old.

$97 \%(\mathrm{n}=97)$ of the subjects were diagnosed with TMJ disorders. For 49,98\% $(\mathrm{n}=48)$ of them disc dislocation with reduction was diagnosed from who for $83,33 \%(\mathrm{n}=40)$ disc dislocation with reduction without jaw locking was diagnosed. For 50,52\% $(n=49)$ of the subjects disc dislocation without reduction was diagnosed. $57,14 \%$ $(n=28)$ of them were diagnosed with disc dislocation without reduction with limited mouth opening and for $42,86 \%(n=21)$ of them disc dislocation without reduction without limited mouth opening was diagnosed. $3 \%(n=3)$ of the subjects had symptoms similar to TMJ disorders but after the evaluation no TMJ disorder was diagnosed.

$86,60 \%(n=84)$ of included subjects suffered from pain in the temporomandibular joint area, in $2 / 3$ of them pain was 
chronic. Arthralgia was diagnosed for $47,42 \%$ of the subjects meanwhile myalgia was diagnosed for $15,46 \%$. Subjects who were diagnosed with disc dislocation without reduction with limited mouth opening statistically more often experienced arthralgia than myalgia $(\mathrm{p}=0,0001)$.

For the majority of the subjects the onset of pain in temporomandibular area was triggered by various factors. $82,14 \%(\mathrm{n}=69)$ of the subjects indicated movements of the mandible to be the main factor causing pain. For $40,47 \%(n=34)$ of the subjects parafunctional habits caused pain in temporomandibular area (Fig.1).

From 84 people who marked in the questionnaire that they were feeling pain in temporomandibular area $28,57 \%(n=24)$ described pain as constant feeling and $71,43 \%(n=60)$ described pain as intermittent. In cases of disc dislocation with reduction without jaw locking and disc dislocation without reduction without limited mouth opening patients statistically more often described pain as intermittent. Also, $65,48 \%(\mathrm{n}=55)$ of the patients described pain as chronic meaning that pain lasted more than six months and $34,52 \%(n=29)$ described pain as acute (lasting less than six months). For patients diagnosed
Table 1. Occlusion evaluation form [18]

\begin{tabular}{|c|c|c|c|c|c|c|}
\hline \multirow{2}{*}{$\begin{array}{l}\text { Characteristic } \\
\text { 1. Was the patient tre- } \\
\text { ated orthodontically? }\end{array}$} & \multicolumn{3}{|c|}{ Yes } & \multicolumn{3}{|c|}{ No } \\
\hline & & & & \\
\hline \multicolumn{7}{|l|}{$\begin{array}{l}\text { 2. Is patient wearing } \\
\text { removable dentures? }\end{array}$} \\
\hline \multicolumn{7}{|l|}{$\begin{array}{l}\text { 3. Are there any lost } \\
\text { teeth? If yes, which } \\
\text { teeth? }\end{array}$} \\
\hline \multicolumn{7}{|l|}{$\begin{array}{l}\text { 4. Is there wear of } \\
\text { canines? }\end{array}$} \\
\hline \multirow[t]{2}{*}{ 5. Angle class } & \multicolumn{3}{|c|}{ Canines } & \multicolumn{3}{|c|}{ First molar teeth } \\
\hline & Class I & Class II & Class III & Class I & Class II & Class III \\
\hline \multicolumn{7}{|l|}{ Right side } \\
\hline \multicolumn{7}{|l|}{ Left side } \\
\hline $\begin{array}{l}\text { 5.1. Angle class II } \\
\text { division }\end{array}$ & \multicolumn{3}{|c|}{ Division I } & \multicolumn{3}{|c|}{ Division II } \\
\hline $\begin{array}{l}\text { 6. Central line of } \\
\text { incisors and facial } \\
\text { central line }\end{array}$ & \multicolumn{3}{|l|}{ Match } & \multicolumn{3}{|c|}{ Do not match } \\
\hline $\begin{array}{l}\text { 7. Central line } \\
\text { between upper and } \\
\text { lower incisors }\end{array}$ & \multicolumn{3}{|l|}{ Match } & \multicolumn{3}{|c|}{ Do not match } \\
\hline $\begin{array}{l}\text { 8. Scissor bite (if yes, } \\
\text { which teeth?) }\end{array}$ & & & & & & \\
\hline
\end{tabular}

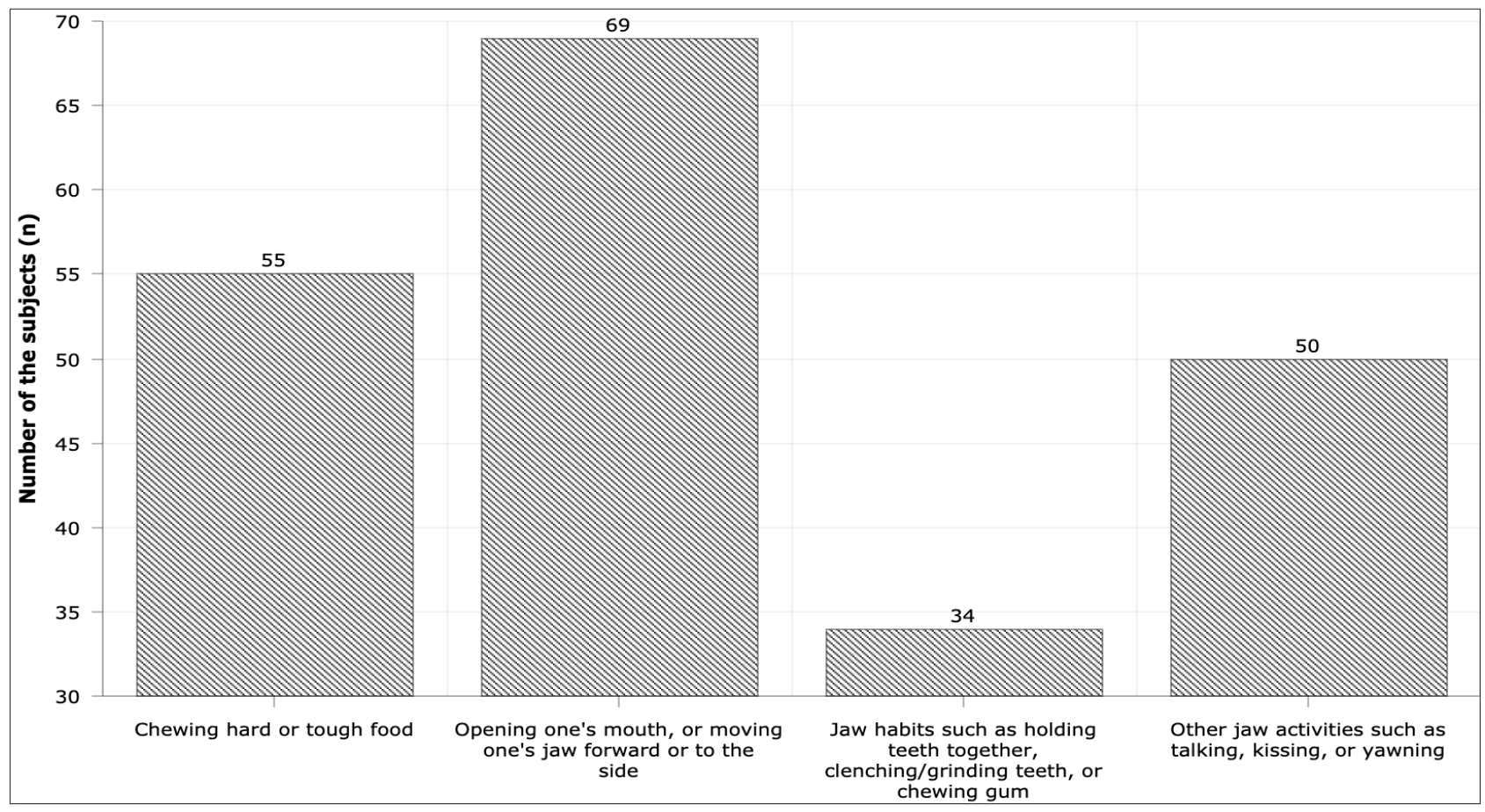

Figure 1. Triggers that cause pain in TMJ area 
with disc dislocation without reduction without jaw locking statistically more often pain was chronic $(\mathrm{p}=0,0001)$.

$89,69 \%(\mathrm{n}=87)$ of the patients diagnosed with TMJ disorder complained about hearing a clicking sound in the temporomandibular area during opening or closing of the mouth.

The most common TMJ disorder amongst all the patients was disc dislocation with reduction without jaw locking. It was diagnosed for $37,18 \%(n=29)$ of the female subjects and for $57,89 \%(n=11)$ of the male subjects.

All patients experienced stress. For $82,47 \%$ of them stress did not have an effect or had only a small effect on their daily life, for $17,53 \%$ stress affected their daily life a lot (Fig.2).

In the age group from 18 to 29 years, patients diagnosed with disc dislocation with reduction experienced medium or high level of stress less often than patients in the age group from 30 years and older. However, patients diagnosed with disc dislocation without reduction in the age group up to 29 years old experienced medium or high level of stress more often than patients in the age group of 30 years and older.

The most common malocclusion for all types of TMJ disorders was Angle class II malocclusion. The relationship between all types of TMJ disorders and Angle class II malocclusion was statistically more often than compared to Angle class I or Angle class III malocclusion.

\section{Discussion}

The main aim of this study was to investigate complaints of patients with TMJ disorders and to determine what factors (gender, age, stress) affect the onset of TMJ disorders. In this study it was also important to investigate the relationship between TMJ disorders and malocclusion. Disc dislocation with reduction without jaw locking was found to be the most common type of TMJ disorder. Patients diagnosed with TMJ disorders in most cases felt chronic pain in the temporomandibular area. TMJ disorders were the most common in the age group between 18 and 29 years of age.

According to the objective examination performed on a patient it was discovered that $97 \%$ of the subjects were diagnosed with TMJ disorder and almost half of them $(49,48 \%)$ suffered from disc dislocation with reduction. The other half $(50,52 \%)$ of the subjects were diagnosed with disc dislocation without reduction. According to a study done in Poland in 2014, disc dislocation with reduction was diagnosed for $44 \%$ of the subjects and according to a study done in Spain in 2009 , the same TMJ disorder was diagnosed for $44,8 \%$ of the subjects $[7,8]$. Disc dislocation without reduction in studies in Poland and in Spain was diagnosed as follows: for $4 \%$ and for $6,5 \%$ of the subjects $[7,8]$. The results may differ because in our study we investigated only the population of

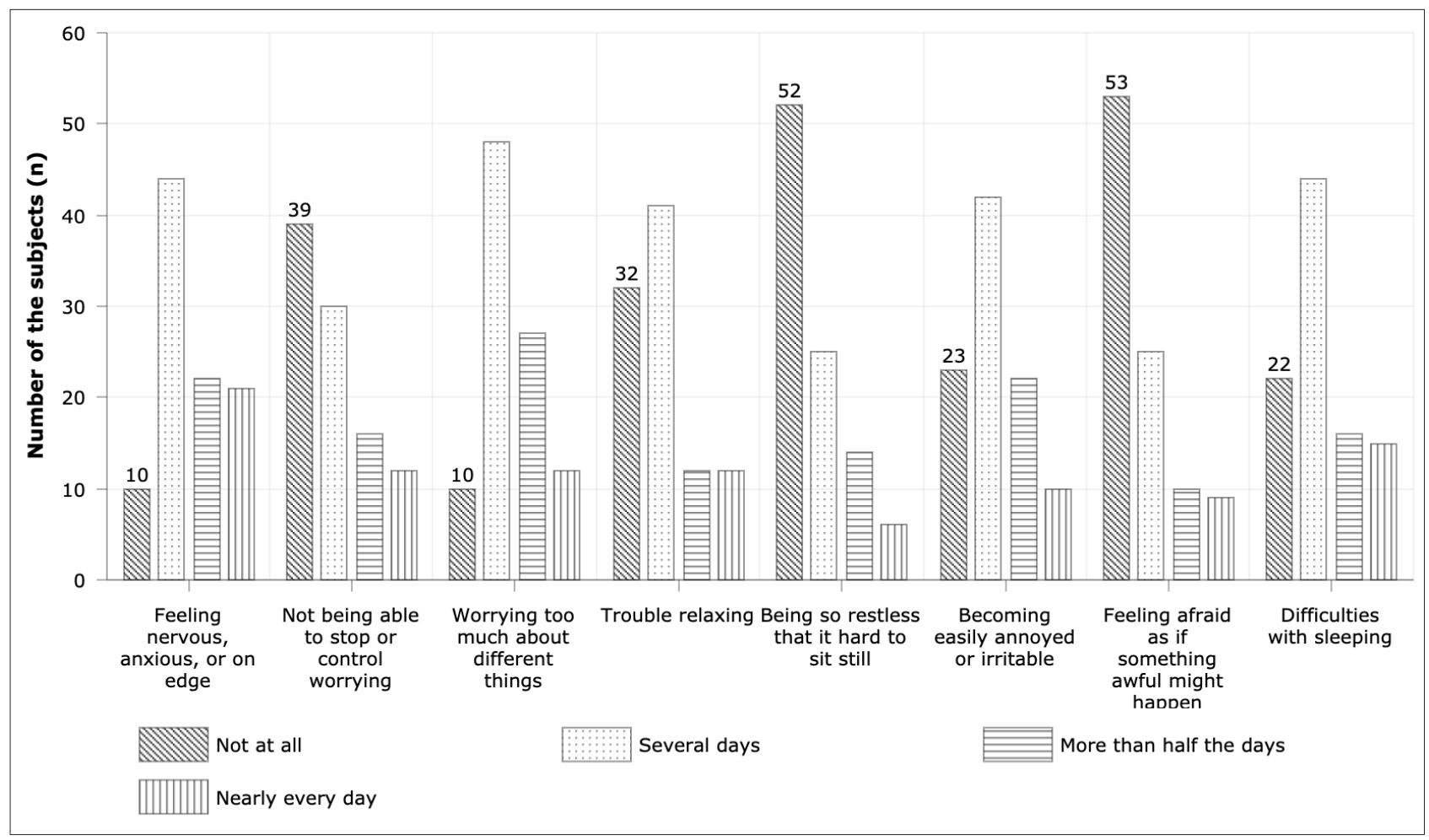

Figure 2. Results of the stress questionnaire 
patients with TMJ disorders and in the studies of other scientists' the focus was on the general population. The results may also differ because in our study the diagnosis obtained during the objective examination was not verified with other additional tests such as MRI. In other scientists' works the diagnosis was confirmed with the MRI test. However, for the majority of the subjects in our study after the MRI test the TMJ disorder diagnosis should be confirmed.

In this study out of 97 subjects that were diagnosed with TMJ disorder more than $80 \%$ complained about pain in temporomandibular area out of which more than half $(65,48 \%)$ complained about pain lasting more than six months. During the objective examination it was found that for all TMJ disorder diagnosis arthralgia was more common except for disc dislocation with reduction when both arthralgia and myalgia was diagnosed. For patients diagnosed with disc dislocation without reduction arthralgia was statistically more often. In early stages of the disorder more pressure is placed on the masticatory muscles, they become overloaded and a patient feels pain accompanied by the pain felt during disc dislocation [9]. When the disorder progresses, dislocated articular disc presses intra-articular structures, these become inflammed and pain in the joint is felt [9]. According to the questionnaires filled out by the patients the most common trigger causing pain is the movement of the lower jaw. More than $82 \%$ of the patients who complained feeling pain named mouth opening or closing and jaw movements to the sides as the main trigger. In our study about $40 \%$ of the subjects who felt pain marked in the questionnaire that parafunctional habits such as clenching or bruxism caused the pain. When evaluating the type of pain, for patients diagnosed with disc dislocation with reduction without jaw locking and disc dislocation without reduction without limited mouth opening statistically more often pain was intermittent. For the first group of patients pain is felt when during mouth opening the condyle presses the bilaminar zone to the articular eminence [4]. Also, for patients diagnosed with disc dislocation with reduction without jaw locking the pain was statistically more often described as chronic. This can be because due to constant movements of the jaw inner structures of the joint are traumatized and in time chronic inflammation starts causing pain [4].

One other frequent complaint of the patients is clicking sound in the temporomandibular joint or ear area. In our study more than $93 \%$ of the subjects diagnosed with TMJ disorder complained about the clicking sound. Clicking can be heard while opening the mouth, while closing the mouth, or both [4]. An opening click signifies recapture of the displaced disc between the articulating joint surfaces [4]. A closing click occurs just prior to tooth contact and is not as loud as the opening click [4]. When the disc becomes nonreducible, i.e. there is no recapture of the disc while opening the mouth, the clicking reduces in intensity or vanishes [4].

Other subjective symptom is jaw locking which is the consequence of the prolonged process of the disorder. Normal TMJ function requires synchronized and coordinated motion of the disk, condylar head, and the muscles of mastication [4]. In the maximum open mouth position, the condylar head should be positioned inferior to the articular eminence and the disk assumes a bow-tie configuration, with the thin intermediate zone situated between the articulating surfaces of the mandibular condyle and the articular eminence [4]. When the inflammation starts the ligaments surrounding the joint elongates due to their lack of elastic fibers and the disc starts moving in relation to the condyle [4]. In later stages of the disorder the displaced disc is markedly thickened and does not reduce upon maximal opening, therefore, the patient experiences jaw locking [10]. In a study performed in Spain in 2009, 24,7\% of the subjects complained of jaw locking [11]. In our study more than $37 \%$ of the patients diagnosed with disc dislocation with reduction suffered from jaw locking which caused great discomfort and difficulties in talking and eating. In our study more than one third of the patients diagnosed with disc dislocation with reduction experienced difficulties with mouth opening and about $10 \%$ had difficulties while eating.

The average age of the patients in the study was 32,9 years. Almost half of the subjects were in the age group between 18 and 29 years old. Other scientific works have proven that TMJ disorders commonly occur in 2 nd to 4 th decade [11]. These are the people of young, productive and reproductive age trying to accomplish something in their lives, therefore, this particular age group experiences higher stress levels that can lead to development of TMJ disorders [12]. Furthermore, it is believed that in the age group 1840 years old important role in the onset of TMJ disorders is played by reproductive hormones [12]. In our study we found that patients younger than 30 years of age experienced higher levels of stress when diagnosed with disc dislocation without reduction and patients older than 30 years of age experienced higher levels of stress when diagnosed with disc dislocation with reduction. It may be due to other factors but according to the results achieved in this study it might be said that because of higher stress levels and higher levels of reproductive hormones TMJ disorders in patients in the age group between 18 and 29 years of age are more prone to become non-reducible.

$80 \%$ of the patients in this study were female and $20 \%$ were male. In the study done in Poland, $70 \%$ of the subjects were female and $30 \%$ were male, however, they investi- 
gated general population, therefore not all of the patients had TMJ disorders [7]. The scientists in this study discovered the tendency that females are more likely to suffer from TMJ disorders. There is a lot of scientific proof that gender effects the onset of TMJ disorders. In our study $37,18 \%$ of the female subjects were diagnosed with disc dislocation with reduction without jaw locking and 35,90\% were diagnosed with disc dislocation without reduction with limited mouth opening. $57,89 \%$ of the male subjects were diagnosed with disc dislocation with reduction without jaw locking and $31,58 \%$ were diagnosed with disc dislocation without reduction without limited mouth opening. Even though it is likely that sex differences exist in basic pain mechanisms that lead to lower pain threshold in females and in associated psychosocial factors, the mechanisms underlying this difference are still not well understood [12]. One explanation to the gender difference has been suggested to be the neural processing concerning pain perception [13]. The nociceptive input may be more easily unregulated into pathological hyperexcitability among women than among men, which may in turn contribute to development of chronic TMJ pain [13]. Based on the results of this study a conclusion can be made that males more often suffer from disc dislocation with reduction without jaw locking and disc dislocation without reduction without limited mouth opening than females. Furthermore, females suffer more often from disc dislocation without reduction with limited mouth opening than males. Moreover, the differences in treatment-seeking behavior between the genders and greater awareness or interest in symptoms between females can also contribute to greater rate of TMJ disorders diagnosed for women [13]. This was proved in our study as well.

One of the main reasons discussed in scientific works that cause TMJ disorders is high levels of stress. In a study performed in Portugal in 2014, were 633 people with TMJ disorders were investigated even $44,2 \%$ of them showed signs of depression and anxiety [14]. In our study we found that at least couple of days during the last two weeks $89 \%$ of the patients felt nervous, anxious or on edge, $60 \%$ were not able to stop or control worrying, more than $89 \%$ of the patients worried too much about different things, $67 \%$ had trouble relaxing, almost half of the patients were restless, more than $76 \%$ were easily annoyed or irritated, $45 \%$ of the subjects felt afraid that something awful might happen and $77 \%$ of the patients had troubles sleeping. However, when asked to evaluate how the stress affected their daily life, patients most commonly said that it made their daily routines somewhat difficult. Stress can provoke parafunctional habits and these can have impact in the onset of TMJ disorders [14]. In our study $40 \%$ of the subjects had parafunctional habits, therefore, it can be believed that stress and parafunctional habits are related to the development of TMJ disorders.

Furthermore, it is believed that malocclusion also plays an important role in the development of TMJ disorders. This relationship is excesively investigated in the scientific world, however, there is no solid opinion. In this study we discovered that Angle class II was the most common one for all types of TMJ disorders. Angle class II was diagnosed for $53,61 \%$ of the patients, meanwhile Angle class III was diagnosed only for $17,53 \%$ of the patients. In a study done in Germany in 2016, scientists diagnosed Angle class II for $14,86 \%$ and Angle class III for $13,51 \%$ of the subjects [15]. A tnedency that Angle class II is the most common one for all types of TMJ disorders can be explained by the factors that appear during the developmental age of the child. There are scientific works which prove that during the development of maxilla and mandible, in skeletal Class II malrelationships, articular compensation (temporomandibular joint) occurs [16]. Moreover, it has been observed that a decreased forward growth of the maxillary and mandibular bodies and a decreased downward growth of the mandibular ramus is associated with TMJ disc dislocation [17]. Also, authors suggest that patients with Angle class II malocclusion in younger age who have suffered from asymptomatic TMJ disorders might develop clinical TMJ disorder symptoms later in life as a result of the progressive loss of their TMJs' adaptive capacity [17]. The literature supports in part the association of TMJ disc displacement with a shorter posterior facial height, a shorter mandibular length and clockwise rotation but these aspects were not investigated in our study [17].

One of the biggest shortcomings of this study was sample size. Even though the number of patients included in this study was quite large and in some cases tendencies can be seen, but in order to get statistically reliable data more patients should be included in the study. In our study we investigated factors that might have influence in the onset of TMJ disorders. Due to wide distribution of the factors across various types of TMJ disorders no concrete conclusions can be made. One more shortcoming of this study is that there was no radiological test performed to confirm the diagnosis. In order to have accurate TMJ disorder diagnosis after the clinical investigation of the patient radiological examination should be performed.

\section{Conclusions}

In a conclusion, according to the results of this study it can be said that the onset of TMJ disorders has a multifactorial etiology and no one reason in particular can be singled out. Our results about prevalence of objective and subjective factors in patients with TMJ disorders coincide 
with the findings of other authors. However, the problem remains relevant and the results of this study show the need to continue the investigation in the future.

\section{References}

1. Al Hayek SO, Al-Thunayan MF, AlGhaihab AM, AlReshaid RM, Omair A. Assessing stress associated with temporomandibular joint disorder through Fonseca's anamnestic index among the Saudi physicians. Clinical and Experimental Dental Research 2018;5(1):52-58.

https://doi.org/10.1002/cre2.157

2. de Melo Júnior PC, Aroucha JMCNL, Arnaud M, Lima MGS, Gomes SGF, Ximenes R, Rosenblatt A, Caldas AF Jr. Prevalence of TMD and level of chronic pain in a group of Brazilian adolescents. PloS One 2019;14(2):e0205874.

https://doi.org/10.1371/journal.pone.0205874

3. Manfredini D, Perinetti G, Guarda-Nardini L. Dental malocclusion is not related to temporomandibular joint clicking: a logistic regression analysis in a patient population. The Angle Orthodontist 2014;84(2):310-315. https://doi.org/10.2319/041613-295.1

4. Mehndiratta A, Kumar J, Manchanda A, Singh I, Mohanty S, Seth N, et al. Painful clicking jaw: a pictorial review of internal derangement of the temporomandibular joint. Polish Journal of Radiology 2019;84:e598-615. https://doi.org/10.5114/pjr.2019.92287

5. Ahmad M, Schiffman EL. Temporomandibular Joint Disorders and Orofacial Pain. Dental Clinics of North America 2016;60(1):105-124.

https://doi.org/10.1016/j.cden.2015.08.004

6. Dzingutė A, Pileičikienè G, Baltrušaitytė A, Skirbutis G. Evaluation of the relationship between the occlusion parameters and symptoms of the temporomandibular joint disorder. Acta medica Lituanica 2017;24(3):167-175.

https://doi.org/10.6001/actamedica.v24i3.3551

7. Wieckiewicz M, Grychowska N, Wojciechowski K, Pelc A, Augustyniak M, Sleboda A, et al. Prevalence and Correlation between TMD Based on RDC/TMD Diagnoses, Oral Parafunctions and Psychoemotional Stress in Polish University Students. BioMed Research International 2014;2014:e472346. https://doi.org/10.1155/2014/472346

8. Poveda-Roda R, Bagán JV, Jiménez-Soriano Y, Fons-Font A. Retrospective study of a series of 850 patients with temporomandibular dysfunction (TMD). Clinical and radiological findings. Medicina Oral, Patologia Oral y Cirugia Bucal 2009; 14(12):e628-634.

https://doi.org/10.4317/medoral.14.e628

9. Poluha RL, Canales GT, Costa YM, Grossmann E, Bonjardim LR, Conti PCR. Temporomandibular joint disc displacement with reduction: a review of mechanisms and clinical presentation. Journal of Applied Oral Science 2019;27:e20180433. https://doi.org/10.1590/1678-7757-2018-0433
10. Murphy MK, Macbarb RF, Wong ME, Athanasiou KA. Temporomandibular Joint Disorders: A Review of Etiology, Clinical Management, and Tissue Engineering Strategies. International Journal Oral Maxillofacial Implants 2013;28(6):e393-414. https://doi.org/10.11607/jomi.te20

11. Ahuja V, Ranjan V, Passi D, Jaiswal R. Study of stress-induced temporomandibular disorders among dental students: An institutional study. National Journal of Maxillofacial Surgery 2018;9(2):147-154 https://doi.org/10.4103/njms.NJMS_20_18

12. Marpaung C, Lobbezoo F, van Selms MKA. Temporomandibular Disorders among Dutch Adolescents: Prevalence and Biological, Psychological, and Social Risk Indicators. Pain Research and Management 2018;2018:e5053709. https://doi.org/10.1155/2018/5053709

13. Rusanen J, Silvola A, Tolvanen M, Pirttiniemi P, Lahti S, Sipilä K. Pathways between temporomandibular disorders, occlusal characteristics, facial pain, and oral health-related quality of life among patients with severe malocclusion. European Journal Orthodontics 2012;34(4):512-517. https://doi.org/10.1093/ejo/cjr071

14. Minghelli B, Morgado M, Caro T. Association of temporomandibular disorder symptoms with anxiety and depression in Portuguese college students. Journal Oral Science 2014;56(2):127-133

https://doi.org/10.2334/josnusd.56.127

15. Manfredini D, Lombardo L, Siciliani G. Dental Angle class asymmetry and temporomandibular disorders. Journal Orofacial Orthopedics 2017;78(3):253-258. https://doi.org/10.1007/s00056-016-0079-4

16. Slavicek R. Relationship between occlusion and temporomandibular disorders: Implications for the gnathologist. American Journal of Orthodontics and Dentofacial Orthopedics 2011;139(1):10-16. https://doi.org/10.1016/j.ajodo.2010.11.011

17. Manfredini D, Segù M, Arveda N, Lombardo L, Siciliani G, Alessandro Rossi, Guarda-Nardini L. Temporomandibular Joint Disorders in Patients With Different Facial Morphology. A Systematic Review of the Literature. Journal of Oral and Maxillofacial Surgery. 2016;74(1):29-46. https://doi.org/10.1016/j.joms.2015.07.006

18. Ohrbach R, editor. Diagnostic Criteria for Temporomandibular Disorders Clinical Protocol and Assessment Instruments. International RDC/TMD Consortium Network. Version 20, 2014. www.rdc-tmdinternational.org

\section{SUBJEKTYVIŲ IR OBJEKTYVIŲ VEIKSNIŲ PAPLITIMAS, ESANT SMILKININIO APATINIO ŽANDIKAULIO SĄNARIO SUTRIKIMU R. Nedzinskaitė, I. Perednytė}

Raktažodžiai: smilkininio apatinio žandikaulio sąnario sutrikimai, orofacialinis skausmas, stresas, netaisyklingas sąkandis. 
Problemos aktualumas ir darbo tikslas. Šio darbo tikslas ịvertinti subjektyvių ir objektyvių veiksnių paplitimą smilkininio apatinio žandikaulio sąnario sutrikimais besiskundžiančiųu populiacijoje.

Metodika. Šis darbas yra ilgalaikio prospektyvinio tyrimo, kuris buvo pradètas 2018 metų rudenį, tęsinys, atliktas Lietuvos sveikatos mokslų universiteto ligoninès, Kauno klinikų ( LSMU KK), Veido ir žandikaulių chirurgijos skyriuje ir Ortodontijos klinikoje. Tyrimą sudarè trys dalys: ekstraoralinis, intraoralinis ištyrimas ir simptomų bei sveikatos klausimynai. Simptomų klausimyną sudare 14 klausimų apie patiriamą skausmą SAŽS srityje. Sveikatos klausimyną sudare 9 klausimai apie patiriamą stresą. Statistinei analizei naudota Microsoft Office Excel ir IBM SPSS Statistics 25 programos. Statistinių ryšių stiprumui nustatyti naudotas t-test nepriklausomoms imtims ir $\chi 2$ testai.

Rezultatai. Dèl ịvairių SAŽS nusiskundimų konsultacijai ị LSMU KK Veido ir žandikaulių chirurgijos skyrių nuo 2019 m. spalio 4 d. iki $2020 \mathrm{~m}$. vasario 4 d. kreipèsi 72 asmenys, iš jų 50 atitiko ịtraukimo ị tyrimą kriterijus. Dar 50 tiriamųjų duomenys buvo ịtraukti iš ankstesnio tyrimo duomenų bazès. Tyrime dalyvavo $80 \%$ moterų ir $20 \%$ vyrų. $49 \%$ tiriamųjų buvo iki 30 metų amžiaus. Skausmu SAŽS srityje skundèsi $86,60 \%$ tiriamųų, iš kurių beveik 2/3 skausmas tęsèsi daugiau nei pusę metų. 97\% tiriamųų buvo diagnozuota SAŽS disko dislokacija, iš kurių 49,98\% nustatyta grị̌̌tama disko dislokacija, 50,52\% negrịžtama disko dislokacija. Visi pacientai patyrè stresą, $82,47 \%$ stresas visai neapsunkino arba tik šiek tiek apsunkino kasdienę veiklą, 17,53\% stresas labai arba itin stipriai apsunkino kasdienę veiklą. Visų SAŽS sutrikimų metu dažniausiai diagnozuotas sąkandžio sutrikimas buvo Angle II klasès.

Išvados. Nustatyta didelè subjektyvių ir objektyvių veiksnių įvairovė, esant SAŽS sutrikimų. Esant SAŽS sutrikimų, dažniausiai pasitaikantis sąkandis buvo Angle II klasès.

Adresas susirašinėti: nedzinskaiter@gmail.com

Gauta 2021-10-24 